Proceedings of the 31st Annual Meeting of the Brazilian Embryo Technology Society (SBTE); Cabo de Santo Agostinho, PE, Brazil, August 17th to 19th, 2017.

\title{
Basic and practical aspects of pregnancy establishment in cattle
}

\author{
Hanne Skovsgaard Pedersen ${ }^{1,4}$, Gianluca Mazzoni ${ }^{2}$, Lotte Stroebech ${ }^{2}$, Haja N. Kadarmideen ${ }^{3}$ Poul Hyttel $^{2}$, \\ Henrik Callesen ${ }^{1}$ \\ ${ }^{1}$ Department of Animal Science, Aarhus University, DK8830 Tjele, Denmark. \\ ${ }^{2}$ Department of Veterinary and Animal Sciences, Faculty of Health and Medical Sciences, University of Copenhagen, DK1870 \\ Frederiksberg C, Denmark. \\ ${ }^{3}$ Department of Bio and Health Informatics, Technical University of Denmark, Kemitorvet, DK2800 Kgs. Lyngby, Denmark.
}

\begin{abstract}
Bovine embryos are increasingly produced using reproductive technologies, e.g. ovum pick-up (OPU), in vitro embryo production (IVP) and embryo transfer (ET). Such in vitro manipulated embryos are known to deviate in several aspects compared to in vivo derived embryos. Pregnancy establishment in cattle involves timed biological events including fine-tuned communication, initiated and carried out by both the embryo and the endometrium. This stimulates research to increase the understanding of events and interactions taking place in the uterus after embryo transfer, both from a biological and systems biology point of view. This review will focus on the biological events taking place during early embryonic development, implantation and beginning of placentation, with focus on transfer of in vitro produced embryos, including a systems biology approach for selection of superior embryo recipients.
\end{abstract}

Keywords: embryo recipient quality, in vitro embryo production, pregnancy establishment, reproductive technologies, systems biology.

\section{Introduction}

For food producing animals such as cattle, reproductive health plays an important role in relation to farm economy and is essential for improving breeding progress. Several biological and management-related factors have an impact on successful fertilization, establishment and maintenance of pregnancy, such as oocyte competence, semen quality, hormone levels, nutrition, milk production and parity. In cattle, the fertilization rate after insemination or natural mating has been estimated to $90 \%$, with an average calving rate of 55\% (Sartori et al., 2002; Diskin et al., 2006; Wiltbank et al., 2016). Most pregnancy losses occur during the early embryonic period, and the biological reasons include both the embryo and the mother in terms of oocyte and embryo quality, impaired function of the endometrium and sub-optimal embryo-maternal communication.

The last decades have shown an increase in both development and use of new technologies for improved reproductive efficiency and for improving the genetic merit of a herd. Among these are ovum pick-up (OPU) followed by oocyte in vitro maturation (IVM), in vitro fertilization (IVF) also using sex-sorted semen, in vitro embryo culture (IVC) and embryo transfer (ET). In 2015 , more than 520,000 in vivo derived and 427,000 in vitro produced bovine embryos were transferred worldwide (Perry, 2016). In vitro produced embryos are still showing impaired results compared to in vivo derived, both in tolerance to cryopreservation, pregnancy rates and early embryo loss (Alberto et al., 2013). To improve the output of OPU-IVP-ET, the identification and selection of high-quality oocyte donors and embryo recipients as well as improved culture systems, resulting in improved embryo development and pregnancy rates, would make these technologies even more attractive.

One important aspect of the increasing use of artificially produced and in vitro manipulated embryos is a growing knowledge about the delicate interactions existing between the embryo and the endometrium. These interactions are dependent on the quality of both parts, the embryo and the endometrium.

This review will focus on the biological events taking place during early embryonic development, implantation and beginning of placentation, with focus on transfer of in vitro produced embryos, including a systems biology approach for selection of superior embryo recipients.

\section{Establishment of the pregnancy}

\section{Early embryonic development}

In the few hours after ovulation of the mature oocyte, gamete interaction occurs in the ampulla of the oviduct. At that time greater portions of the oocyte's zona pellucida is devoid of cumulus cells and the fertilizing spermatozoon has easy access to the zona surface (Hyttel et al., 1988). At 2-3 h after ovulation, the spermatozoon has undergone the acrosome reaction, penetrated zona pellucida, and both the sperm head and tail are found in the ooplasm. Consequently, the oocyte is activated resulting in resumption of meiosis and release of the cortical granules that elicits zona hardening and the resulting block to polyspermic penetration. Over the coming hours, the second polar body is abstracted, and smooth endoplasmic reticulum is attracted to the sperm head as well as to the retained maternal chromatin in order to build nuclear envelopes of the two pronuclei. Around 5-7 $\mathrm{h}$ after ovulation, the pronuclei have developed to spherical structures that

${ }^{4}$ Corresponding author: Hanne.Skovsgaard@anis.au.dk 
migrate to close apposition around $15-19 \mathrm{~h}$ after ovulation. During this developmental period the S-phase of the first mitotic cell cycle takes place (Laurincik et al., 1994). At around $20 \mathrm{~h}$, the nuclear envelopes are dissolved into the smooth endoplasmic reticulum, and the maternal and paternal chromosomes align during formation of the prophase and metaphase of the first mitotic division.

Around $24 \mathrm{~h}$ after ovulation, the cleavage to the 2-cell stage occurs followed by two rather short cell cycles bringing the embryo to the 8 -cell stage. This fourth cell cycle is considerably longer and includes major activation of the embryonic genome during which process the blastomere's nucleoli are activated to initiate transcription and ribosome production (King et al., 1988; Laurincik et al., 2000). Around the morula stage (16-32 cells), the embryo passes from the oviduct to the uterus.

With the activation of the embryonic genome, the embryo achieves the ability to form different cell lineages, and at the 16-32-cell stage compaction of the morula occurs. The pluripotent inner cell mass (ICM) is formed, and the outer trophectoderm (TE) is sealed by tight junctions and desmosomes and develops water transporting capacity leading to the formation of the fluid filled blastocyst. Around day 8 after ovulation, the blastocyst hatches from the zona pellucida.

Around the time of hatching, the ICM develops into an upper pluripotent epiblast and a lower epithelium, the hypoblast (Maddox-Hyttel et al., 2003). The latter epithelium develops on the inside of the blastocyst to form an inner lining of both the epiblast and the TE. Around day 12, the TE covering of the epiblast (Rauber's layer) becomes extremely thin, and finally the epiblast penetrates the TE and becomes incorporated into the outer layer of the conceptus, which at this time of development is two-layered. The epiblast establishes the embryonic disc of pluripotent cells that will give rise to the embryo proper.

Around day 14 after ovulation, the embryonic disc initiates gastrulation by formation of the primitive streak through which cells start to ingress to form endoderm and mesoderm. The endoderm becomes integrated in the hypoblast whereas the mesoderm forms a loose mesenchyme between the epiblast and the hypoblast as well as the longitudinal rod, the notochord (Maddox-Hyttel et al., 2003). The epiblast located longitudinally over the notochord will develop into the neural ectoderm, whereas the more peripheral parts of the overlying epiblast will develop into the surface ectoderm. Along with the development of the embryonic disc and gastrulation, the conceptus elongates to a length of several centimeters on day 15 after ovulation at the time of embryonic-maternal signaling.

The implantation process begins day 16-18, i.e. after embryo elongation, with placentation starting around day 22. Implantation and placentation occur at the caruncular areas of the endometrium. Reduction or loss of an anti-adhesive molecule from the uterine endometrium is necessary to prepare for implantation. Also, an appearance of cell-adhesion molecules (e.g.
Integrins) on the surface of the endometrium is important to attachment and invasion (Mansouri-Attia et al., 2009). Fusions of placental cotyledons with the caruncles form placentomes that are involved in fetalmaternal gas exchange and provision of nutrients.

\section{Maternal-embryonic communication}

From the mid-1970ies, the view on maternalembryonic communication during early pregnancy has changed. At that time, the function of the oviduct and the uterine horn was considered to simply keep and transport the gametes under proper conditions, but with no specialized signaling and interaction. In some ways, the success with in vitro embryo production (IVP) during the same period only supported such a view, also because these processes could be performed in a welldefined medium at the right temperature and atmosphere. However, the reports on Large Offspring Syndrome (LOS) from the early 1990ies challenged this view (e.g. Lazarri et al., 2002), even though the solution seemed to be a simple reduction in serum concentration in IVP media.

Parallel to the technological omics-revolution, a quite new insight into the mechanisms has gradually appeared, illustrating that the events are complex, interactive and fine-tuned involving both the embryo and the endometrium. The complex biological events have been expressed as "Thus, a receptive endometrium, an implantation-competent blastocyst and a synchronized dialogue between maternal and embryonic tissues is a pre-requisite for successful implantation" (Salilew-Wondim et al., 2012).

Today, it is well described that there is "crosstalking" going on at many points of the reproductive process in different species (e.g. Oestrup et al., 2011; Alminana et al., 2012; Forde et al., 2012a; SalilewWondim et al., 2012; Ulbrich et al., 2013; Fazelli and Holt, 2016; Klein, 2016). This cross-talking reflects quality at several points with some species differences, but the overall pattern is the same. In the oviduct, it involves timing of ovulation, tuba collection of the ovulated cumulus-oocyte-complex, the oocyte-sperm interactions and oviductal cilia movements to transport the zygote and early embryo (Avilés et al., 2015; Maillo et al., 2016a). In vivo, it has been demonstrated in mice that unfertilized vs fertilized oocytes trigger a different gene response in the oviduct (Lee et al., 2002), and in the horse are unfertilized oocytes not allowed to pass the utero-tubal junction, probably influenced by missing embryo secretion of prostaglandin E2 (Klein, 2016). Today, the active role of the oviduct is becoming more and more clear with a growing list of activities both as preparation for an embryo to arrive as well as reactions to its actual presence (Artemenko et al., 2015; GonellaDiaza et al., 2015, 2017; Maillo et al., 2016b). One challenge for this kind of work seems to be able to detect the changes when they are only caused by a single embryo (Maillo et al., 2015).

Some of the cross-talking involves presence of semen in the reproductive tract. The first reports were in vitro studies with oviduct epithelial cells responding to 
the presence of spermatozoa in cattle (Ellington et al., 1993) and in horse (Thomas et al., 1995). Since then, a number of studies have demonstrated various reactions in the oviduct from the arrival of sperm (Maillo et al., 2016b), also showing that the oviduct seems to be able to differentiate between $\mathrm{X}$ - and Y-bearing spermatozoa (Alminana et al., 2014). Seminal plasma is described to have a positive influence on embryo development, implantation and pregnancy in different species, although there are mixed results with respect to bovine (Maillo et al., 2016b). In several species has an ovulation-inducing-factor been demonstrated in seminal fluid that induces ovulation and possibly influences the properties of the progesterone-producing capacity of the corpus luteum (Ratto et al., 2012).

In the uterus, the interaction and communication continues through hatching and implantation. The hatching is a mutual process, where the embryo is active with collapses and re-expansions, the zona is thinned by secretion of trypsin from the endometrium, and small projections of specialized cellular TE through the zona induce the focal opening(s) through one of which the embryo escapes, aided by TE proteinase secretion (Kirkegaard et al., 2013). In human, an active embryo secretion seems to be essential for establishment of the pregnancy (Brosens et al., 2014).

Mechanisms of communication between embryo and recipient are also under investigation. It has been known for a longer time that an immunological reaction is initiated by the alien sperm/embryo that alert the maternal immune system, however without rejection of the gametes (Fazelli and Holt, 2016). Therefore, it must be well under control, and interferon (IFN-t) secreted by the elongating conceptus (around day 15 in cattle to block luteal regression) is considered to be one of the most important candidates in regulating the immune response (Oestrup et al., 2011). During the last ten years a messenger system including small vesicles has appeared (miRNA, exosomes; Saadeldin et al., 2015) that is so far speculated to be one way of communication between the maternal tract and the gametes (Maillo et al., 2016b).

Taken together, it is getting more and more clear that there is a testing of process and product quality going on at several points during the early phase of the reproductive process - and that this has regulatory consequences, sometimes resulting in embryonic/fetal loss, sometimes leading to long-term effects observed in the offspring (e.g. Fleming et al., 2015).

\section{Preparations in the embryo recipient}

During the estrous cycle, the cow prepares herself for a potential pregnancy by establishing an environment supporting embryonic development (Pohler et al., 2012; Atkins et al., 2013). High levels of estradiol produced by ovarian follicles during proestrous and estrous result in increased uterine blood flow, promote uterine contractions assisting sperm transport, and affect the uterine environment increasing the chance of embryo survival, possibly by sustaining embryonic growth and the development of placenta (Madsen et al., 2015) The ovulatory follicle's production of estradiol and the subsequent corpus luteum's progesterone production are now also shown to be related to changes in tissue, cells and secretions in both the oviduct (Gonella-Diaza et al., 2015, 2017) and the uterus (Binelli et al., 2015). These changes are also stimulated by the conceptus (INF-t, prostaglandins, cortisol), and the endometrium (prostaglandins, cortisol), and altogether are affecting uterine physiology and receptivity (Forde et al., 2009, 2011). The uterine preparation for pregnancy includes thickening of the endometrium and development of uterine muscles and glands, including production of uterine histotroph required for embryo survival and growth. The histotroph consists of different substances (e.g. amino acids, carbohydrates, proteins, lipids) transported into the uterine lumen by endometrial epithelial cells from the blood and as specific secretory products encoded by genes expressed in the endometrial epithelium (Bazer, 1975; Gray et al., 2001; Forde et al., 2014). Embryo development in uterine-gland knock-out sheep has shown to be retarded from day 9-14, indicating the importance of the endometrial epithelial secretions (Gray et al., 2002).

On the molecular level, the progesteroneinduced changes in gene expression in the endometrium result in up- or down-regulation of genes involved in processes such as cellular transports, cell cycle, cell growth and differentiation, lipogenesis, metabolism, cell adhesion, signal transduction, biosynthesis and immune response (Bauersachs et al., 2006; Forde et al., 2009, 2011, 2012b; Simmons et al., 2009; Binelli et al., 2015). The progesterone-induced changes in the endometrial transcriptome seem to be independent of pregnancy status up to the time of conceptus elongation and maternal recognition of pregnancy on day 15 (Forde et al., 2011), but an embryo-dependent programming of endometrial function has recently been demonstrated already from day 7 in the estrous cycle (Sponchiado et al., 2017). Also on day 7, Binelli et al. (2015) showed endometrial gene expressions in the uterine horn contralateral to an AI that illustrated the readiness and preparedness of the endometrium to receive an incoming embryo. In addition, pretransfer endometrial biopsies from heifers on day 7 of the estrous cycle revealed differences in gene expression according to pregnancy diagnosis in the following cycle after transfer of in vivo derived embryos (Salilew-Wondim et al., 2010) and in vitro produced embryos (Ponsuksili et al., 2012). Differences in endometrial gene expression have shown to be related to the chance of pregnancy in fertility-classified heifers on day 14 (Minten et al., 2013). For pregnant animals, a difference in endometrial gene expression was demonstrated on day 17 between fertile and subfertile dairy cow strains (Walker et al., 2012). This information on endometrial transcriptomic profiles express the status of uterine receptivity at least at a given time, but it is still not known how well it can characterize that animal (or strain).

As stated above, progesterone stimulates and 
maintains endometrial functions necessary for a pregnancy establishment. Insufficient plasma progesterone concentrations have been linked to poor embryo development and maternal-embryonic signaling in terms of decreased INF-t production by the embryo (Mann and Lemming, 2001), and high levels of progesterone have shown to advance conceptus elongation (Carter et al., 2008). Several studies have investigated the effect of exogenous post-insemination progesterone treatment in heifers and cows, but results differ with regard to a potential beneficial effect on embryo development and pregnancy outcome (Sreenan and Diskin, 1983; Mann and Lamming, 1999; Yan et al., 2016).

\section{In vitro produced embryos}

In vitro produced embryos are in general less robust in establishing pregnancies compared to their in vivo counterparts. In terms of cryopreservation, in vitro produced embryos have decreased survival rates post-thawing after conventional freezing and postwarming after vitrification (Papadopoulos et al., 2002). Furthermore, there are morphological differences such as an overall lower cell number of both TE and ICM compared to in vivo derived embryos (Farin et al., 1995). The increasing use of in vitro produced embryos adds a challenge to the successful outcome of ET, and prediction of embryo quality prior to transfer could result in a major improvement of pregnancy rate.

The impact of culture conditions during IVP on bovine embryos is still not sufficiently investigated, and therefore the knowledge of how this parameter is reflected in the pregnancy establishment can be improved. It is, however, well known that culture conditions and IVP media have a high impact on embryonic gene expression and hence on embryo quality. Addition of serum to the embryo culture medium was earlier considered to cause abnormalities during pregnancy and at calving (LOS; Lazzari et al., 2002; Chen et al., 2013). This problem was to a high degree reduced considerably after use of serum-reduced or serum-free media, but the incidence of LOS still creates concern in commercial IVP also today. Other aspects of using reproductive technologies have been identified, such as an increase in the frequency of epigenetic abnormalities that may lead to congenital malformation syndromes including higher birth weight (DeBaun et al., 2003). Therefore, thorough control of conditions in the IVP laboratory as well as the protocol for embryo production could improve embryo quality and thus the overall IVP result. One example is the conditions during shipping of oocytes, a procedure that has increased enormously the last decade, that has been demonstrated to have a large impact on embryo development (Hashem et al., 2017). Furthermore, freezing and vitrification protocols also influence epigenetics and should be taken into consideration in attempting to further reduce the LOS incidences.

It is therefore still a major objective to increase the knowledge of embryo quality assessment to improve establishment of pregnancies and healthy live born offspring in both human assisted reproductive technologies as well as the cattle industry. Presently, few predictors are available for embryo quality evaluation. The subjective characterization based mainly on embryo morphology and kinetics is an insufficient predictor for IVP embryo survival and pregnancy outcome; however, it is still the most commonly used method. Other available in vitro techniques to assess embryo quality are hatching rates, degree of apoptosis (Antunes et al., 2010), chromosome analyses and to a lesser degree gene expression techniques (Jakobsen et al., 2006). More recent technologies are focusing more on developing new noninvasive methods, such as infrared spectroscopy to predict embryo quality and sex after analysis of spent culture medium (Gomez et al., 2008; Munoz et al., 2014). To monitor kinetics during early embryonic development assessing cleavage rate, synchronicity and even-sized blastomeres through time-lapse systems is widely used within the human IVF industry and has increased in the recent years (e.g. Kovacs, 2014). Metabolomics and proteomics profiling technologies may allow determination of the metabolites associated with embryo viability and thereby predicting pregnancy outcome (Gardner et al., 2001; Sturmey et al., 2010). Metabolomics, the newest emerging technology, includes analysis of spent culture media for the small non-coding RNA, including microRNA (Rødgård et al., 2015), demonstrated to be important to embryogenesis and development (Goossens et al., 2013). Therefore, new screening tools based on embryo quality and viability assessment could have a huge impact on prediction of pregnancy rates and the efficiency of ET programs with IVP embryos.

\section{Application of quantitative genetics for selection of embryo recipients}

While the heritability of fertility traits is low (0.05), OPU-IVP related traits (number of cumulusoocyte complexes, quality of cumulus-oocyte complexes, number and proportion of cleaved embryos at day 4, and number and proportion of total and transferable embryos at day 7 of culture) have shown a heritability from 0.10 to 0.25 (Merton et al., 2009). Thus, genetic improvement could be faster for ART traits such as OPU-IVP-ET than for conventional fertility traits in dairy cattle (Kadarmideen et al., 2000). Alternative approaches have to select successfully for this type of traits, and a possibility is to use molecular genomic information in animal breeding including genomic selection (GS; Kadarmideen, 2014).

Genomic selection is based on computing genomic estimated breeding values (GEBVs) by estimating SNP effects from prediction equations (Meuwissen et al., 2001). Two major advantages of genomic selection compared with traditional selection based on pedigree and phenotype alone are: (i) it can select animals accurately early in life using their GEBVs from genomic prediction and (ii) increased accuracy of GEBVs for phenotypes that are very difficult or expensive to measure including fertility 
(Hayes et al., 2013). Genomic selection has made a substantial economic impact (Kadarmideen, 2014; Suravajhala et al., 2016) increasing the genetic gain or income with $60-120 \%$ compared to traditional methods of progeny testing and performance tests in livestock (Schaeffer, 2006; Pryce and Daetwyler, 2012). Numerous genomic prediction models have been developed, which vary according to several assumptions regarding the variance of traits of interest and the distribution of the SNP effect.

The principles behind genomic selection of recipient cows is the same as for any traditional phenotype in cattle breeding. Genomic prediction accuracy gets better with increasing trait heritability and reference population used for calculating GEBVs. Before applying any quantitative genetics or breeding method, the high quality reproductive data recording traits will be an essential step. Thus, it is important to set up a reference population where a large number of recipient cattle are recorded for pregnancy rates after OPU-IVP-ET. Once a good reference population is collected, the Best Linear Unbiased Prediction (BLUP) methods (e.g. GBLUP and single-step BLUP) (Henderson, 1975; Meuwissen et al., 2001; Aguilar et al., 2010; Goddard et al., 2011) can produce GEBVs for all these animals. Based on the ranking of GEBVs, breeding animals can then be selected and used in OPUIVP-ET, increasing the recipient cattle reproductive performance, i.e. pregnancy success.

In this context, integrative systems biology could provide useful information for GS. IVP and ET performances are complex traits, so more holistic approaches are needed to identify biological mechanisms and biomarkers associated with these traits. Systems biology approaches identify the emerging properties of a biological system (Kitano, 2002; Breitling, 2010). Therefore, systems biology represents a promising tool for OPU-IVP-ET related traits. The function of the endometrium is important to the chance of embryo implantation in recipient cows. Therefore, transcriptomic of endometrial tissue can be used to perform systems biology analysis of recipient cow performances (Orozco-Lucero and Sirard, 2014). The biological mechanisms and the molecular markers identified through the systems biology analysis of transcriptomic data could be integrated in multi-omics analysis, for example eQTL studies. The eQTL studies integrate transcriptomic with genomic data to identify genomic regions controlling the expression of a certain gene (Westra and Franke, 2014). If the expression of the genes is associated to the trait of interest, the eQTL identified can be indirectly associated with the traits (Ponsuksili et al., 2010). The information provided by integrative systems biology studies, for example eQTLs, could be included in GS methods utilizing functional information.

The understanding of the biological basis of the molecular regulation of the complex reproductive events is improving significantly these years. One main reason is the fruitful interaction between the biological and molecular sciences that form a very strong platform, and the combined action "can provide a strong continuation to the understanding of traits related to ARTS" (Mazzoni et al., 2017).

\section{Conclusions and perspectives}

The establishment of a pregnancy in cattle includes interactions between the embryo and the mother at all stages of the pregnancy. Timed biological events and communication take place to maintain and accomplish the pregnancy and to reach the final goal, i.e. the birth of a healthy live offspring. The embryo and the endometrium handle and adapt to different challenges and conditions, based on signaling from both sides and influenced by e.g. the use of reproductive technologies and the origin of the embryo. Also, many factors affect uterine receptivity and finally, the synchrony between the embryo and recipient is important. Therefore, to improve in vitro embryo production conditions and to increase the output from OPU-IVP-ET, it is highly relevant to continue the research into the complex biological mechanisms, but also to further investigate and develop methods based on a systems biology approach. One ultimate goal for this combined action will be to obtain a tool to improve selection of recipients for transfer of in vitro produced embryos.

\section{Acknowledgments}

Authors acknowledge the funding from grant \#2012/50533-2, São Paulo Research Foundation (FAPESP) and the Programme Commission on Health, Food and Welfare of the Danish Council for Strategic Research for the GIFT project (www.gift.ku.dk).

\section{References}

Aguilar I, Misztal I, Johnson D, Legarra A, Tsuruta S, Lawlor TJ. 2010. Hot topic: a unified approach to utilize phenotypic, full pedigree and genomic information for genetic evaluation of Holstein final Score. J Dairy Sci, 93:743-752.

Alberto ML, Meirelles FV, Perecin F, Ambrósio CE, Favaron PO, Franciolli ALR, Mess AM, Dos Santos JM, Rici REG, Bertolini M, Miglino MA. 2013. Development of bovine embryos derived from reproductive techniques. Reprod Fertil Dev, 25:907-917.

Alminana C, Heath PR, Wilkinson S, SanchezOsorio J, Cuello C, Parrilla I, Gil MA, Vazuez JL, Vazquez JM, Roca J, Martinez EA, Fazeli A. 2012. Early developing pig embryo mediate their own environment in the maternal tract. PLoS One, 7:e33625. doi.org/10.1371/journal.pone.0033625.

Alminana C, Caballero, Heath PR, Maleki-Dizaji S, Parrilla I, Cuello C, Gil MA, Vazquez JL, Vazquez JM, Roca J, Martinez EA, Holt WV, Fazeli A.. 2014. The battle of sexes starts in the oviduct: modulation of oviductal transcriptome by $\mathrm{X}$ and Y-bearing spermatozoa. BMC Genomics, 15:293. doi: 10.1186/1471-2164-15-293

Antunes G, Chaveiro A, Santos P, Marques A, Jin HS, Moreira da Silva F. 2010. Influence of apoptosis in bovine embryo's development. Reprod Domest Anim, 


\section{5:26-32.}

Artemenko K, Horáková J, Steinberger B, Besenfelder U, Brem G, Bergquist J, Mayrhofer C. 2015. A proteomic approach to monitor the dynamic response of the female oviductal epithelial cell surface to male gametes. $J$ Proteomics, 113:1-14. doi: 10.1016/j.jprot.2014.09.016.

Atkins JA, Smith MF, MacNeil MD, Jinks EM, Abreu FM, Alexander LJ, Geary TW. 2013. Pregnancy establishment and maintenance in cattle. $J$ Anim Sci, 91:722-733.

Avilés M, Coy P, Rizos D. 2015. The oviduct: a key organ for the success of early reproductive events. Anim Front, 5:25-31.

Bauersachs S, Ulbrich SE, Gross K, Schmidt SEM, Meyer HHD, Wenigerkind $H$, Vermehren $M$, Sinowatz F, Blum H, Wolf E. 2006. Embryo-induced transcriptome changes in bovine endometrium reveal species-specific and common molecular markers of uterine receptivity. Reproduction, 132:319-331.

Bazer FW. 1975. Uterine protein secretions: relationship to development of the conceptus. J Anim Sci, 41:1376-1382.

Binelli M, Scolari SC, Pugliesi G, Van Hoeck V, Gonella-Diaza AM, Andrade SCS, Gasparin GR, Coutinho LL. 2015. The transcriptome signature of the receptive bovine uterus determined at early gestation. PLoS On2: 10:e0122874. doi: 10.1371/journal.pone.0122874.

Breitling R. 2010. What is systems biology? Front Physiol, 1:9. doi: 10.3389/fphys.2010.00009.

Brosens JJ, Salker MS, Teklenburg G, Nautiyal J, Salter S, Lucas ES, Steel JH, Christian M, Chan YW, Boomsma CM, Moore JD, Hartshorne GM, Sućurović S, Mulac-Jericevic B, Heijnen CJ, Quenby S, Koerkamp MJ, Holstege FC, Shmygol A, Macklon NS. 2014. Uterine selection of human embryos at implantation. Sci Rep, 4:3894. doi: 10.1038/srep03894.

Carter F, Forde N, Duffy P, Wade M, Fair T, Crowe MA, Evans AC, Kenny DA, Roche JF, Lonergan P. 2008. Effect of increasing progesterone concentration from day 3 of pregnancy on subsequent embryo survival and development in beef heifers. Reprod Fertil Dev, 20:368-375.

Chen Z, Hagen DE, Elsik CG, Ji T, Morris CJ, Moon LE, Riviera RM. 2013. Characterization of global loss of imprinting in fetal overgrowth syndrome induced by assisted reproduction. Proc Natl Acad Sci USA, 112:4618-4623.

DeBaun MR., Niemitz EL, Feinberg AP. 2003. Association of in vitro fertilization with beckwithwiedemann syndrome and epigenetic alterations of LIT1 and H19. Am J Hum Genet, 72:156-160.

Diskin MG, Murphy JJ, Sreenan JM. 2006. Embryo survival in dairy cows managed under pastoral conditions. Anim Reprod Sci, 96:297-311.

Ellington JE, Ignotz GG, Ball BA, Meyers-Wallen VN, Currie WB. 1993. De novo protein synthesis by bovine uterine tube (oviduct) epithelial cells changes during co-culture with bull spermatozoa. Biol Reprod, 48:851-856.

Farin PW, Britt JH, Shaw DW, Slenning BD. 1995. Agreement among evaluators of bovine embryos produced in vivo or in vitro. Theriogenology, 44:339-349.

Fazelli A, Holt WV. 2016. Cross talk during the periconception period. Theriogenology, 86:438-442.

Fleming TP, Watkins AJ, Sun C, Velazquez MA, Smyth NR, Eckert JJ. 2015. Do little embryos make big decisions? How maternal dietary protein restriction can permanently change and embryo's potential, affecting adult health. Reprod Fertil Dev, 27:684-692.

Forde N, Carter F, Fair T, Crowe MA, Evans AC, Spencer TE, Bazer FW, McBride R, Boland MP, O'Gaora P, Lonergan P, Roche JF. 2009. Progesterone-regulated changes in endometrial gene expression contribute to advanced conceptus development in cattle. Biol Reprod, 81:784-794.

Forde N, Beltman ME, Duffy GB, Duffy P, Mehta JP, Ó'Gaora P, Roche JF, Lonergan P, Crowe MA. 2011. Changes in the endometrial transcriptome during the bovine estrous cycle: effect of low circulating progesterone and consequences for conceptus elongation. Biol Reprod, 84:266-278.

Forde N, Duffy GB, McGettigan PA, Browne JA, Mehta JP, Kelly AK, Mansouri-Attia N, Sandra O, Loftus BJ, Crowe MA, Fair T, Roche JF, Lonergan P, Evans AC. 2012a. Evidence for an early endometrial response to pregnancy in cattle: both dependent upon and independent of interferon tau. Physiol Genomics, 44:799-810.

Forde N, Mehta JP, Minten M, Crowe MA, Roche JF, Spencer TE, Lonergan P. 2012b. Effects of low progesterone on the endometrial transcriptome in cattle. Biol Reprod, 87:124, 1-11. doi: 10.1095/biolreprod.112.103424.

Forde N, McGettigan PA, Mehta JP, O'Hara L, Mamo S, Bazer FW, Spencer TE, Lonergan P. 2014. Proteomic analysis of uterine fluid during the preimplantation period of pregnancy in cattle. Reproduction, 147:575-587.

Gardner DK, Lane M, Stevens J, Schoolcraft WB. 2001. Noninvasive assessment of human embryo nutrient consumption as a measure of developmental potential. Fertil Steril, 76:1175-1180.

Goddard ME, Hayes BJ, Meuwissen THE. 2011. Using the genomic relationship matrix to predict the accuracy of genomic selection. J Anim Breed Genet, 128:409-421.

Gómez E, Rodríguez A, Muñoz M, Caamaño JN, Hidalgo CO, Morán E, Facal N, Díez C. 2008. Serum free embryo culture medium improves in vitro survival of bovine blastocysts to vitrification. Theriogenology, 69:1013-1021.

Gonella-Diaza AM, da Silva Andrade SC, Sponchiado M, Pugliesi G, Mesquita FS, Van Hoeck V, de Francisco Strefezzi R, Gasparin GR, Coutinho LL, Binelli M. 2015. Size of the ovulatory follicle dictates spatial differences in the oviduct transcriptome in cattle. PLoS One, 10:e0145321. doi: 10.1371/journal.pone.0145321.

Gonella-Diaza AM, da Silva Andrade SC, Sponchiado M, Pugliesi G, Mesquita FS, Van Hoeck V, de Francisco Strefezzi R, Gasparin GR, Coutinho LL, Binelli M. 2017. Oviductal transcriptional profiling of a bovine fertility mdel by next-generation 
sequencing. Genomics Data, 13:27-29.

Goossens K, Mestdagh P, Lefever S, Van Poucke M, Van Zeveren A, Van Soom A, Vandesompele J, Peelman L. 2013. Regulatory microRNA network identification in bovine blastocyst development. Stem Cells Dev, 22:1907-1920.

Gray CA, Bartol FF, Tarleton BJ, Wiley AA, Johnson GA, BAzer FW, Spencer TE. 2001. Developmental biology of uterine glands. Biol Reprod, 65:1311-1323.

Gray CA, Burghardt RC, Johnson GA, BAzer FW, Spencer TE. 2002. Evidence that absence of endometrial gland secretions in uterine gland knockout ewes compromises conceptus survival and elongation. Reproduction, 124:289-300.

Hashem N, Secher, J. Pryor JH, Long CR, Looney CR, Avery B, Hyttel P, Stroebech L. 2017. Bovine embryo development rates are affected when oocytes are matured in different vials containing HEPES/Bicarbonate buffered medium. Reprod Fertil Dev, 29:179. doi: 10.1071/RDv29n1Ab141.

Hayes BJ, Lewin HA, Goddard ME. 2013. The future of livestock breeding: genomic selection for efficiency, reduced emissions intensity, and adaptation. Trends Genet, 29:206-214.

Henderson CR. 1975. Best linear unbiased estimation and prediction under a selection model. Biometrics, 31:423-447.

Hyttel P, Greve T, Callesen H. 1988. Ultrastructure of in vivo fertilization in superovulated cattle. $\mathrm{J}$ Reprod Fertil, 82:1-13.

Jakobsen AS, Thomsen PD, Avery B. 2006. Few polyploid blastomeres in morphologically superior bovine embryos produced in vitro. Theriogenology, 65:870-881.

Kadarmideen HN, Thompson R, Simm G. 2000. Linear and threshold model genetic parameters for disease, fertility and milk production in dairy cattle. Anim Sci, 71:411-419.

Kadarmideen HN. 2014. Genomics to systems biology in animal and veterinary sciences: progress, lessons and opportunities. Livest Sci, 166:232-248.

King WA, Niar A, Chartrain I, Betteridge KJ, Guay P. 1988. Nucleolus organizer regions and nucleoli in preattachment bovine embryos. J Reprod Fertil, 82:87-95.

Kirkegaard K, Hindkjaer JJ, Ingerslev HJ. 2013. Hatching of in vitro fertilized human embryos is influenced by fertilization method. Fertil Steril, 100:1277-1282.

Kitano H. 2002. Systems biology: a brief overview. Science, 295:1662-1664.

Klein C. 2016. Maternal recognition of pregnancy in the context of equine embryo transfer. J Equine Vet Sci 41:22-28.

Kovacs P. 2014. Embryo selection: the role of timelapse monitoring. Reprod Biol Endocrinol, 12:124. doi: 10.1186/1477-7827-12-124.

Laurincik J, Kopecny V, Hyttel P.1994 Pronucleus development and DNA synthesis in bovine zygotes in vivo. Theriogenology, 42:1285-1293.

Laurincik J, Thomsen PD, Hay-Schmidt A, Avery B, Greve T, Ochs RL, Hyttel P. 2000. Nucleolar proteins and nuclear ultrastructure in preimplantation bovine embryos produced in vitro. Biol Reprod, 62:1024-1032.

Lazzari G, Wrenzycki C, Herrmann D, Duchi R, Kruip T, Niemann H, Galli C. 2002. Cellular and molecular deviations in bovine in vitro-produced embryos are related to the Large Offspring Syndrome. Biol Reprod, 67:767-775.

Lee KF, Yao YQ, Kwok KL, Xu JS, Yeung WS. 2002. Early developing embryos affect the gene expression patterns in the mouse oviduct. Biophys Res Commun, 292:564-570.

Maddox-Hyttel P, Alexopoulus NI, Vajta G, Lewis I, Rogers $\mathbf{P}$, Cann $\mathbf{L}$, Callesen $\mathbf{H}$, Tveden-Nyborg $\mathbf{P}$, Trounson A. 2003. Immunohistochemical and ultrastructural characterization of the initial posthatching development of bovine embryos. Reproduction, 125:607-623.

Madsen CA, Perry GA, Mogck CL, Daily RF, MacNeil MD, Geary TW. 2015. Effects of preovulatory estradiol on embryo survival and pregnancy establishment in beef cows. Anim Reprod Sci, 158:96-103

Maillo V, Gaora PÓ, Forde N, Besenfelder U, Havlicek V, Burns GW, Spencer TE, GutierrezAdan A, Lonergan P, Rizos D. 2015. Oviduct-embryo inteactions in cattle: two-way traffic or a one-way street? Biol Reprod, 92:144, 1-8. doi: 10.1095/biolreprod.115.127969.

Maillo V, Lopera-Vasquez R, Hamdi M, GutierrezAdan A, Lonergan P, Rizos D. 2016a. Maternalembryo interaction in the bovine oviduct: Evidence from in.-vivo and in vitro studies. Theriogenology, 86:443-450

Maillo V, Sáchez-Calabuig MJ, Lopera-Vasquez R, Hamdi M, Gutierrez-Adan A, Lonergan P, Rizos D. 2016b. Oviductal response to gametes and early embryos in mammals. Reproduction, 152:R127-R141

Mann GE, Lamming GE. 1999. The influence of progesterone during early pregnancy in cattle. Reprod Domest Anim, 34:269-274.

Mann GE, Lamming GE. 2001. Relationship between maternal endocrine environment, early embryo development and inhibition of the luteolytic mechanism in cows. Reproduction, 121:175-180.

Mansouri-Attia N, Sandra O, Aubert J, Degrelle S, Everts RE, Giraud-Delville C, Heyman Y, Galio L, Hue I, Yang X, Cindy Tian X, HA, Renard J-P. 2009. Endometrium as an early sensor of in vitro embryo manipulation technologies. Proc Natl Acad Sci USA, 106:5687-5692.

Mazzoni G, Pedersen HS, Oliveira Junior GA, Alexandre P, Razza EM, Callesen H, Hyttel P, Nogueira MFG, Ferraz JBS, Kadarmideen HN. 2017. Application of integrative genomics and systems biology to conventional and in vitro reproductive traits in cattle. Anim Reprod, 14:507-513.

Merton JS, Ask B, Onkundi DC, Mullaart E, Colenbrander B, Nielen M. 2009. Genetic parameters for oocyte number and embryo production within a bovine ovum pick-up-in vitro production embryoproduction program. Theriogenology, 72:885-893.

Meuwissen THE, Hayes BJ, Goddard ME. 2001. 
Prediction of total genetic value using genome wide dense marker maps. Genetics, 157:1819-1829.

Minten MA, Bilby TR, Bruno RGS, Allen CC, Madsen CA, Wang Z, Sawyer JE, Tibary A, Neibergs HL, Geary TW, Bauersachs S, Spencer TE. 2013. Effects of fertility on gene expression and function of the bovine endometrium. PLoS One, 8:e69444. doi: 10.1371/journal.pone.0069444.

Muñoz M, Uyar A, Correia E, Díez C, FernandezGonzalez A, Caamaño JN, Martínez Bello D, Trigal B, Humblot P, Ponsart C, Guyader-Joly C, Carrocera S, Martin D, Marquant Le Guienne B, Seli E, Gomez E. 2014. Prediction of pregnancy viability in bovine in vitro-produced embryos and recipient plasma with Fourier transform infrared spectroscopy. J Dairy Sci, 97:5497-5507.

Oestrup E, Hyttel P, Oestrup O. 2011. Embryomaternal communication: signalling before and during placentation in cattle and pig. Reprod Fertil Dev, 23:964-975.

Orozco-Lucero E, Sirard MA. 2014. Molecular markers of fertility in cattle oocytes and embryos: progress and challenges. Anim Reprod, 11:183-194.

Papadopoulos S, Rizos D, Duffy P, Wade M, Quinn K, Boland MP, Lonergan P. 2002. Embryo survival and recipient pregnancy rates after transfer of fresh or vitrified, in vivo or in vitro produced ovine blastocysts. Anim Reprod Sci, 74:35-44.

Perry G. 2016. International Embryo Technology Society (IETS). Embryo Technol Newslett, 34:10-25.

Pohler KG, Geary TW, Atkins JA, Perry GA, Jinks EM, Smith MF. 2012. Follicular determinants of pregnancy establishment and maintenance. Cell Tissue Res, 349:649-664.

Ponsuksili S, Murani E, Schwerin M, Schellander K, Wimmers K. 2010. Identification of expression QTL (eQTL) of genes expressed in porcine M. longissimus dorsi and associated with meat quality traits. $B M C$ Genomics, 11:572. doi: 10.1186/1471-2164-11-572.

Ponsuksili S, Murani E, Schwerin M, Schellander K, Tesfaye D, Wimmers K. 2012. Gene expression and DNA-methylation of bovine pretransfer endometrium depending on its receptivity after in vitro produced embryo transfer. PLoS One, 7:e42402. doi: 10.1371/journal.pone.0042402.

Pryce J, Daetwyler H. 2012. Designing dairy cattle breeding schemes under genomic selection: a review of international research. Anim Prod Sci, 52:107-114.

Ratto MH, Leduc YA, Valderrama XP, Van Straaten KE, Delbaere LTJ, Pierson RA, Adams GP. 2012. The nerve of ovulation-inducing factor in semen Proc Natl Acad Sci USA, 109:15042-15047.

Rødgård, TH, Heegaard P, Callesen H. 2015. Noninvasive assessment of in vitro embryo quality to improve transfer success. Reprod Biomed Online, 31:585-592.

Saadeldin IM, Oh HJ, Lee BC. 2015. Embryonicmaternal cross-talk via exosomes: potential implications. Stem Cells Cloning, 8:103-107.

Salilew-Wondim D, Hölker M, Rings F, Ghanem N, Ulas-Cinar M, Peippo J, Tholen E, Looft C, Schellander K, Tesfaye D. 2010. Bovine pretransfer endometrium and embryo transcriptome fingerprints as predictors of pregnancy success after embryo transfer. Physiol Genomics, 42:201-218.

Salilew-Wondim D, Schellander K, Hoelker M, Tesfaye D. 2012. Oviductal, endometrial and embryonic gene expression patterns as molecular clues for pregnancy establishment. Anim Rep Sci, 134:9-18.

Sartori R, Sartor-Bergfelt R, Mertens SA, Guenther JN, Parrish JJ, Wiltbank MC. 2002. Fertilization and early embryonic development in heifers and lactating cows in summer and lactating and dry cows in winter. $J$ Dairy Sci, 85:2803-2812.

Schaeffer L. 2006. Strategy for applying genome wide selection in dairy cattle. J Anim Breed Genet, 123:218223.

Simmons RM , Erikson DW, Kim J, Burghardt RC, Bazer FW, Johnson GA, Spencer TE. 2009. Insulinlike growth factor binding protein one in the ruminant uterus: potential endometrial marker and regulator of conceptus elongation. Endocrinology, 150:4295-4305.

Sponchiado M, Gomes NS, Fontes PK, Martins T, Del Collado M, Pastore AA, Puglies G, Nogueira MFG, Binelli M. 2017. Pre-hatching embryo-dependent and - independent programming of endometrial function in cattle. PLoS One, 12:e0175954. doi: 10.1371/journal.pone.0175954.

Sreenan JM, Diskin MG. 1983. Early embryonic mortality in the cow: its relationship with progesterone concentration. Vet Rec, 112:517-521.

Sturmey RG, Bermejo-Alvarez P, Gutierrez-Adan A, Rizos D, Leese HJ, Lonergan P. 2010. Amino acid metabolism of bovine blastocysts: A biomarker of sex and viability. Mol Reprod Dev, 77:285-296.

Suravajhala P, Kogelman LJ, Kadarmideen HN. 2016. Multi-omic data integration and analysis using systems genomics approaches: methods and applications in animal production, health and welfare. Genet Sel Evol, 48:38. doi: 10.1186/s12711-016-0217-x.

Thomas PGA, Ball BA, Brinsko SP. 1995. Changes associated with induced capacitation influence the interaction between equine spermatozoa and oviduct epithelial cell monolayers. Biol Reprod Mono, 1:697705.

Ulbrich SE, Wolf E, Bauersachs S. 2013. Hosting the preimplantation embryo: potentials and limitations of diffferent approaches for analysing embryoendometrium interactions in cattle. Reprod Fertil Dev, 25:62-70.

Walker CG, Littlejohn MD, Mitchell MD, Roche JR, Meier S. 2012. Endometrial gene expression during early pregnancy differs between fertile and subfertile cow strains. Physiol Genomics, 44:47-58.

Westra HJ, Franke L. 2014. From genome to function by studying eQTLs. Biochim Biophys Acta, 1842:18961902.

Wiltbank MC, Baez GM, Garcia-Guerra A, Toledo MZ, Monteiro PL, Melo LF, Ochoa JC, Santos JE, Sartori R. 2016. Pivotal periods for pregnancy loss during the first trimester of gestation in lactating dairy cows. Theriogenology, 86:239-253.

Yan L, Robinson R, Shi Z, Mann G. 2016. Efficacy of progesterone supplementation during early pregnancy in cows: a meta-analysis. Theriogenology, 85:1390-1398. 